\title{
Flowcytometric Analysis of Cell Cycle in the Liver of Mice in vivo Exposed to $(+)$ - $\alpha$-Viniferin, a Phytostilbene
}

Roy B* and Pathaw D

Department of Zoology, North-Eastern Hill University, Shillong, India

*Corresponding author: Roy B, Department of Zoology, North-Eastern Hill University, Shillong, India, Tel: 00913642722331; E-mail: bishnuroy12@rediffmail.com

Received date: September 13, 2017; Accepted date: September 20, 2017; Published date: September 27, 2017

Copyright: (C) 2017 Roy B, et al. This is an open-access article distributed under the terms of the Creative Commons Attribution License, which permits unrestricted use, distribution, and reproduction in any medium, provided the original author and source are credited.

\begin{abstract}
In vitro anticancer and anthelmintic properties of the phytostilbene (+)- $\alpha$-viniferin had been established. However, contradictory reports are available about the mode of action of the chemical. Therefore, an in vivo investigation was carried out to see whether or not the cell cycle arrest is the cause of cell death in the albino mice exposed to (+)- $\alpha$ viniferin. Cell cycle was analysed in the liver cells of albino mice treated with different concentrations of the phytochemical, through flow cytometer. The results showed a constant dose dependent $(1 \mathrm{mg}$ to $5 \mathrm{mg}(+)-\alpha-$ viniferin/kg body weight of mice) increase in number of cells in the SubG1 stage of cell cycle along with a steady decrease in the number of cells in $G_{0} / G_{1}$ phase. Thus no cell cycle arrest was evident in any phase of cell cycle in the mice exposed to different concentration of $(+)$ - $\alpha$-viniferin. The flow cytometric results were also supported by histochemical observations of large number of dead cells in the liver section of mice in vivo exposed to $(+)$ - $\alpha-$ viniferin. An increase in cell death with an increase in the doses of the phytochemical as observed in the present study need to be study further to elucidate the mechanism of action of the compound leading the death of the liver cells in mice.
\end{abstract}

Keywords: Cell cycle; Albino mice; (+)-a-viniferin; Phytochemical

\section{Introduction}

Increased demand for phytomedicine in different parts of the globe is credited to the idea that "Green medicine" is not only easily available and cheap but also safe to consume [1]. However, review of literature revealed that the chemicals present in many traditionally used medicinal plants exert irreparable damage to liver, kidney, heart, brain, intestine and reproductive organs of its consumers [2-4]. (+)- $\alpha-$ viniferin $\left(\mathrm{C}_{42} \mathrm{H}_{30} \mathrm{O}_{9}\right)$ is a polyphenolic phytoalaxin that naturally occurs in different traditionally used medicinal plants [5-11]. Thus a good quantity of the chemical is consumed regularly by economically weaker section of people in the developing country like India, through crude extract of different plants as folk medicine [12].

In Northeast India, different tribes consume $3 \mathrm{mg}$ to $4 \mathrm{mg}$ crude extract of Carex baccans (having $200 \mu \mathrm{M}$ to $250 \mu \mathrm{M}(+)-\alpha-$ viniferin)/ $\mathrm{kg}$ body weight/day continuously for $10 \mathrm{~d}$ to $15 \mathrm{~d}$ to cure intestinal helminth infection. It is reported that the phytochemical is toxic to cancerous cells and its toxicity is carried out through apoptotic cell death in several cancer cell lines [13]. However, Gonzalez-Sarrias et al. [10] observed that (+)- $\alpha$-viniferin do not induce apoptosis in vitro, but arrest cell cycle in colon cancer cells. Therefore, because of its public health significance, an in vivo experiment was carried out involving (+)- $\alpha$-viniferin to see whether or not the chemical induces cell cycle arrest leading to death of liver cells of albino mice.

\section{Materials and Methods}

\section{Instruments and chemicals}

Flow cytometer (FACSCalibur, Becton-Dickinson), gentleMACS Dissociator (Miltenyi Biotec, USA). Centrifuge, CELLQuest Pro software, fluorescence microscope (EVOS FL, Lifetechnologies), (+)- $\alpha$ viniferin, propidium iodide solution $(50 \mu \mathrm{g} / \mathrm{ml}$ propidium iodide with $0.2 \mathrm{mg} / \mathrm{ml} \mathrm{RNase)}$ in phosphate buffer saline $\mathrm{pH} 7.4$, chilled $70 \%$ ethanol, gentleMACS C tubes, MACS SmartStrainers $(100 \mu \mathrm{m}$ pore size), red blood cell lysis solution (10 X), Krebs-Ringer-Buffer (154 $\mathrm{mM} \mathrm{NaCl}, 5.6 \mathrm{mM} \mathrm{KCl}, 5.5 \mathrm{mM}$ glucose, $20.1 \mathrm{mM}$ HEPES, $25 \mathrm{mM}$ $\left.\mathrm{NaHCO}_{3} \mathrm{pH} 7.4\right), 0.5 \mathrm{M} \mathrm{CaCl}$ solution, $0.2 \mathrm{M} \mathrm{MgCl}$ solution, collagenase IV solution (containing 5000 collagenase digestion units/mL in KRB), DNase I solution (containing 30,000 U/mL DNase I in KRB buffer. PEB buffer (Phosphate buffered saline with 0.5\% BSA and 2 mM EDTA; pH 7.2). DAPI (stock) solution (1 mg of 4', 6' diamino-2-phenylindole $2 \mathrm{HCl}$ in $1 \mathrm{ml}$ distilled water), DAPI working solution $(1 \mu \mathrm{l} / \mathrm{ml}$ was prepared from the DAPI stock solution in $1 \mathrm{X}$ PBS), dimethyl sulfoxide (DMSO).

\section{Animals and treatment}

Experiment on animals was performed in accordance to the guidelines of OECD 407 [14] and Animal Ethics Committee's guidelines for laboratory animal use and care, North-Eastern Hill University, Shillong, India. The mice were kept in metal cages in the animal house having uniform temperature of $25^{\circ} \mathrm{C}$ with $12 \mathrm{~h}$ light and $12 \mathrm{~h}$ dark periodicity. The animals were fed with standard feed and water ad libitum. All the mice were acclimatized for two weeks before starting the experiment. A total of 24 mice were separated in to four groups having six mice of either sex (3 males and 3 females) in each group. Different concentrations (1.0 mg, $2.0 \mathrm{mg}$ and $5.0 \mathrm{mg}$ ) of (+)- $\alpha-$ viniferin per kg body weight of mice were administered orally once a day with the help of a gastric feeding tube. Control animals were fed up with PBS having $0.1 \%$ DMSO only. Administration of (+)- $\alpha$-viniferin and vehicle (PBS having .1\% DMSO) continued for $14 \mathrm{~d}$, followed by starvation of mice for overnight. On day 15th, each mouse was anesthetized with chloroform and sacrificed for collection of liver. 
Page 2 of 4

For preparation of single cell suspension, the liver from control and $(+)$ - $\alpha$-viniferin treated mice were dissected out and single-cell suspension was prepared using gentleMACS Dissociators (as per manufacturer direction). Briefly, the liver was washed in Krebs Ringer Buffer and transferred into $\mathrm{C}$ Tube containing pre-warmed $\left(37^{\circ} \mathrm{C}\right)$ dissociation mix which contains $4.4 \mathrm{~mL} \mathrm{KRB,} 20 \mu \mathrm{L} \mathrm{CaCl}$ solution, 50 $\mu \mathrm{L} \mathrm{MgCl}_{2}, 500 \mu \mathrm{L}$ collagenase Type IV $(500 \mathrm{CDU} / \mathrm{mL})$ and $25 \mu \mathrm{L}$ DNase I solution $(150 \mathrm{U} / \mathrm{mL})$. The $\mathrm{C}$ tube was closed tightly and attached upside down on the sleeve of the gentleMACS Dissociator. The gentleMACS Program m_liver_01 was run. After termination of the program, the $\mathrm{C}$ Tube was detached and incubated at $37^{\circ} \mathrm{C}$ for 30 min under slow continuous rotation. Again, the C Tube was attached onto the gentleMACS Dissociator and the program m_liver_02 was run. After termination of the program, the $\mathrm{C}$ tube was detached and a short centrifugation step was performed to collect the sample at the tube bottom (optional). The sample was resuspended and filtered into a $50 \mathrm{~mL}$ tube using MACS SmartStrainer (pore size $100 \mu \mathrm{m}$ ) pre wet with PEB buffer. The MACS SmartStrainer was washed with additional $10 \mathrm{~mL}$ PEB buffer. The MACS SmartStrainer was discarded and $10 \mathrm{~mL}$ of PEB buffer was added to the sample collected. The cell suspension was centrifuge at $17 \mathrm{xg}$ to $21 \mathrm{xg}$ for $4 \mathrm{~min}$ at $4^{\circ} \mathrm{C}$ to remove contaminating hepatocytes. The supernatant containing the target cells was collected and transfer to a new $50 \mathrm{~mL}$ tube rinsed with PEB buffer. The cell suspension was centrifuged again at $300 \mathrm{xg}$ for $10 \mathrm{~min}$ at $4^{\circ} \mathrm{C}$ and the supernatant was discarded. The pellet was resuspended in 1 $\mathrm{mL}$ PEB buffer and $10 \mathrm{~mL}$ of RBC Lysis solution was added to it. After $5 \mathrm{~min}$ of incubation at room temperature, $30 \mathrm{~mL}$ of PEB buffer was added and centrifuged at $300 \mathrm{xg}$ for $10 \mathrm{~min}$ at $4^{\circ} \mathrm{C}$. The supernatant was discarded while the pellet was resuspended in $1 \mathrm{~mL}$ to $2 \mathrm{~mL}$ of PEB buffer and the final volume was made to $30 \mathrm{~mL}$ with PEB. Again the cell suspension was centrifuged at $300 \mathrm{xg}$ for $10 \mathrm{~min}$ at $4^{\circ} \mathrm{C}$. The supernatant was discarded while the pellet was resuspended with PEB buffer to the required volume for further applications.

Isolated cells were fixed with 70\% ethanol, washed in PBS and resuspended in $500 \mu \mathrm{l}$ of propidium iodide solution for $30 \mathrm{~min}$ at room temperature in dark. 10,000 cells were acquired for each sample and analysed with a FACSCalibur. The distribution of cells in the cell cycle was measured by CELLQuest Pro software.

For microscopic observations of dead cells, liver tissue of mice from control and (+)- $\alpha$-viniferin treated mice were fixed in $4 \%$ paraformaldehyde and processed for sectioning. Liver sections $(8 \mu \mathrm{m}$ to $10 \mu \mathrm{m})$ were then washed in PBS 3 times for $5 \mathrm{~min}$ each and incubated with DAPI solution in dark for $10 \mathrm{~min}$ at room temperature. The sections were washed with PBS 3 times, mounted on a slide in $70 \%$ glycerol and viewed under a fluorescence microscope.

\section{Results and Discussion}

Figure 1 depict the flow cytometric cell count and its relative DNA content in the liver cells of control and (+)- $\alpha$-viniferin $(1 \mathrm{mg}, 2 \mathrm{mg}$ and $5 \mathrm{mg} / \mathrm{kg}$ body weight) treated mice. The population of cells in each phase was measured by a flow cytometer and was gated in histogram with $\mathrm{M} 1\left(\mathrm{G}_{0} / \mathrm{G}_{1}\right.$ phase), M2 (M phase), M3 (S phase) and M4 (sub$\left.G_{1}\right)$. The $M 4$ gate indicates the sub-diploid DNA fraction and represents dead cells. The proportion of M4 increased gradually when the dose of (+)- $\alpha$-viniferin increased from $1 \mathrm{mg}$ to $5 \mathrm{mg} / \mathrm{kg}$ body weight. The percentage of cells in each phases of cell cycle is shown in Table 1. An increased in gated percentage in Sub G1 (M4) fraction from $9.89 \%$ at a dose of $1 \mathrm{mg} / \mathrm{kg}$ body weight to $21.7 \%$ at $2 \mathrm{mg} / \mathrm{kg}$ body weight and finally to $26.35 \%$ at $5 \mathrm{mg} / \mathrm{kg}$ body weight was observed when compared with that of the control (4\%). This observation was accompanied by a gradual decreased in cell count from $83.49 \%$ at a dose of $1 \mathrm{mg} / \mathrm{kg}$ body weight to $73.48 \%$ at $2 \mathrm{mg} / \mathrm{kg}$ body weight and finally to $65.79 \%$ at $5 \mathrm{mg} / \mathrm{kg}$ body weight when compared to control which revealed to be $87.91 \%$ in $\mathrm{G}_{0} / \mathrm{G}_{1}$ (M1) phase (Table 1).

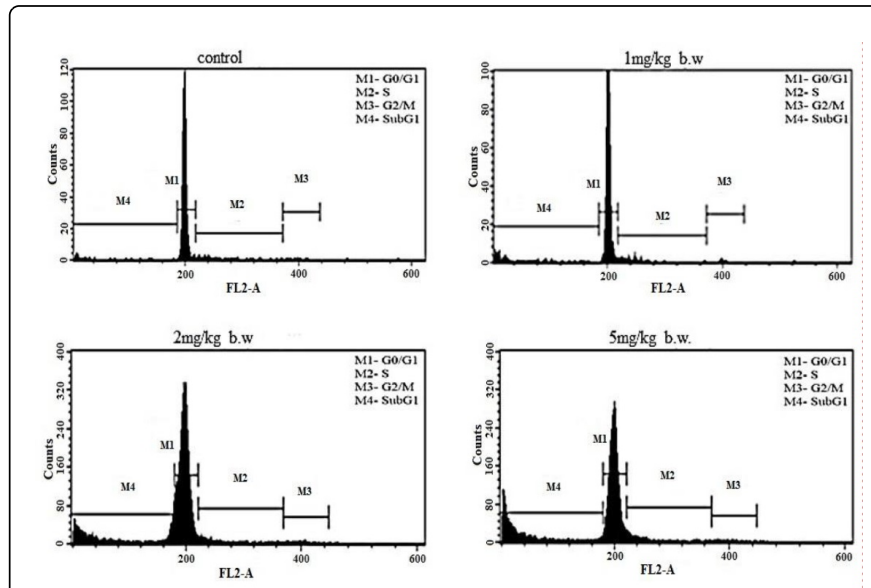

Figure 1: Flow cytometric histogram of control, $1 \mathrm{mg} / \mathrm{kg}, 2 \mathrm{mg} / \mathrm{kg}$, and $5 \mathrm{mg} / \mathrm{kg} \alpha$-viniferin treated mice. X-axis denotes cell count, Yaxis denotes relative DNA content. 10,000 cells were acquired for each sample. $M 1$ denotes $G_{0} / G_{1}$ population, $M 2$ denotes $S$ population, M3 denotes $\mathrm{G}_{2} / \mathrm{M}$ population and M4 denotes $\mathrm{SubG}_{1}$ (dead cells) fraction.

\begin{tabular}{|c|c|c|c|c|}
\hline Stages & $\begin{array}{l}\text { Control } \\
\text { (\%) }\end{array}$ & $1 \mathrm{mg} / \mathrm{kg}$ body weight (\%) & $2 \mathrm{mg} / \mathrm{kg}$ body weight (\%) & $5 \mathrm{mg} / \mathrm{kg}$ body weight (\%) \\
\hline $\mathrm{G}_{0} / \mathrm{G}_{1}$ & 87.91 & 83.49 & 73.48 & 65.79 \\
\hline S & 6.66 & 5.91 & 4.69 & 6.69 \\
\hline $\mathrm{G}_{2} / \mathrm{M}$ & 1.23 & 0.71 & 1.43 & 1.45 \\
\hline SubG $_{1}$ & 4 & 9.89 & 21.7 & 26.35 \\
\hline
\end{tabular}

Table 1: Gated percentage of liver cells of mice (in different phases of cell cycle) treated with (+)- $\alpha$-viniferin at doses of $1 \mathrm{mg} / \mathrm{kg}$ body weight, 2 $\mathrm{mg} / \mathrm{kg}$ body weight and $5 \mathrm{mg} / \mathrm{kg}$ body weight in comparison to control. SubG1 fractions represent dead cells. 
DAPI stained liver cells of control mice showed large and uniformly stained nucleus, most of which are round in shape having intact nuclear membrane (Figure 2A). Mice treated with different concentrations of $(+)$ - $\alpha$-viniferin showed increased number of dead cells with increased doses and characterized by brightly stained condensed nuclei having disintegrated nuclear membrane (Figure 2B-2D).

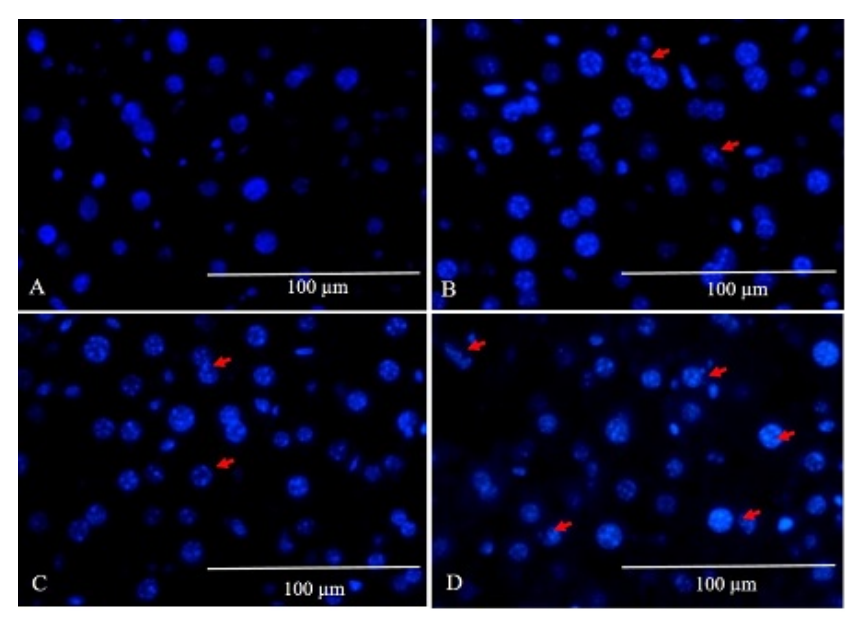

Figure 2: Micrographs showing DAPI stained nucleus of liver sections of control and $(+)$ - $\alpha$-viniferin treated mice. A: Control; B: Mice treated with $1 \mathrm{mg}(+)-\alpha$-viniferin/kg body weight; C: Mice treated with $2 \mathrm{mg}(+)$-a-viniferin/kg body weight; D: Mice treated with $5 \mathrm{mg}(+)-\alpha$-viniferin/kg body weight of mice. Sections of $\alpha-$ viniferin treated mice show presence of dead cells characterized by condensed chromatin which are brightly stained by DAPI, some of which also shows disintegrating nucleus (red arrow) when compared with control.

Cell division leading to formation of genetically identical daughter cells depends on four steps i.e. G1 (gap), S (synthesis), G2 and M (mitosis) phases of cell cycle. Between synthesis and multiplication phases, there are check points to check the status of DNA, so that the event of cycle can progress to the next phase. If any abnormality occurs in the genetic information, this has to be repaired first, and in such cases cell cycle arrest take place. In the event of irreparable damage, cell cycle arrest can lead to cell death [15]. Cellular response for cell cycle arrest is temporary and activated immediately following DNA damage by toxic substances, however, cell death response is a delayed process which correlates with the persistence to DNA damage resulting elimination of affected cell [16].

In the present study the percentage of SubG1 population of cells increased gradually as the concentration of $(+)$ - $\alpha$-viniferin increased, with the concomitant decrease in $G_{0} / G_{1}$ stage of cells. The flow cytometric results was also supported by the histochemical observation of an increased numbers of dead cells in DAPI stained liver cells of mice exposed to different concentration of $(+)-\alpha$-viniferin. Though the number of dead cells increased with increased concentration of the phytochemical, no indication of cell cycle arrest at any stage of cell cycle was evident. In vitro study carried out on human colon cancer cells demonstrated that $(+)$ - $\alpha$-viniferin inhibit proliferation of colon cancer cells by inducing cell cycle arrest, but not apoptosis [10]. However, Chowdhury et al. [13] observed that the phytochemical is pro-apoptotic to several cancer cell lines as it causes caspase dependent apoptotic cell death.

DNA condensation and fragmentation as observed in the DAPI stained nucleus of liver cells of $(+)$ - $\alpha$-viniferin treated mice indicate probable involvement of caspase dependent mechanism of cell death. It is also established that nuclear translocation of apoptosis inducing factor in response to toxin's signals occurs in mammalian cells resulting nuclear condensation and DNA fragmentation [17]. Since DNA fragmentation can result from activation of caspase or the nuclear translocation of apoptosis inducing factor, it is prerequisite to carry out a thorough investigation to elucidate the exact mechanism of DNA damage leading to cell death in the mice treated with (+)-aviniferin.

\section{Conclusion}

Based on the present observations, it may be concluded that (+)- $a-$ viniferin is toxic to mice as different concentrations of the chemical cause cell death in liver. Further it is noted that death of liver cells in (+)- $\alpha$-viniferin treated mice do not occur due to cell cycle arrest. Therefore, further in vivo investigation should be carried out to elucidate the mechanism of action of the phytochemical.

\section{Acknowledgements}

This study was supported by a research grant from the Department of Science and Technology, Govt. of India, New Delhi. Infrastructural facilities provided by the Department of Zoology and Department of Biotechnology and Bioinformatics, North-Eastern Hill University, Shillong, India are also acknowledged.

\section{References}

1. Parekh J, Chanda S (2006) In vitro antimicrobial activities of extracts of Launaea procumbens Roxb. (Labiateae), Vitis vinifera L. (Vitaceae) and Cyperus rotundus $\mathrm{L}$. (Cyperaceae). Afr J Biomed Res 9: 89-93.

2. Ernst E (2003) Serious psychiatric and neurological adverse effects of herbal medicines: A systemic review. Acta Psychiatr Scand 108: 89-93.

3. Lima CF, Fernandes-Ferreira M, Fereira-Wilson C (2007) Drinking of Salvia officinalis tea increases CCl4-induced hepatotoxicity in mice. Food Chem Toxicol 45: 456-464.

4. Giri BR, Roy B (2013) Nephrotoxic potential of Carex baccans (Family: Cyperaceae): A light and electron microscopic studies. J Toxicol Health 103: 244-251.

5. Kurihara H, Kawabata J, Ichikawa S, Mishima M, Mizutani J (1991) Oligostilbenes from Carex kobomugi. Phytochemistry 30: 649-653.

6. Lee SH, Shin NH, Kang SH, Park J, Chung S, et al. (1998) Alpha-viniferin: A prostaglandin $\mathrm{H} 2$ synthase inhibitor from root of Carex humilis. Planta Medica 64: 204-207.

7. Sung SH, Kang SY, Lee KY, Park MJ, Kim JH, et al. (2002) (+)- $\alpha$-Viniferin, a stilbene trimer from Caragana chamlague, inhibit acetylcholinesterase. Biol Pharm Bull 25: 125-127.

8. Fiorentino A, Abrosca BD, Izzo A, Pacifico S, Monaco P (2006). Structural elucidation and bioactivity of novel secondary metabolites from Carex distachya. Tetrahedron 62: 3259-3265.

9. Li L, Henry GE, Seeram NP (2009) Identification and Bioactivities of Resveratrol Oligomers and Flavonoids from Carex folliculata Seeds. J Agric Food Chem 57: 7282-7287.

10. Gonzalez-Sarrias A, Gromek S, Niesen D, Seeram NP, Henry GE (2011) Resveratrol oligomers isolated from Carex species inhibit growth of human colon tumorigenic cells mediated by cell cycle arrest. J Agric Food Chem 59:8632-8638. 
Citation: Roy B, Pathaw D (2017) Flowcytometric Analysis of Cell Cycle in the Liver of Mice in vivo Exposed to (+)- $\alpha$-Viniferin, a Phytostilbene . Clin Exp Pharmacol 7: 243. doi:10.4172/2161-1459.1000243

Page 4 of 4

11. Roy B, Giri BR (2016) $\alpha$-Viniferin and resveratrol induced alteration in the activities of some energy metabolism related enzymes in the cestode parasite Raillietina echinobothrida. Acta Trop 154:102-106.

12. Giri BR, Roy B (2015) Resveratrol and $\alpha$-viniferin induced alterations of acetylcholinesterase and nitric oxide synthase in Raillietina echinobothrida. Parasitol Res 114: 3775-3781.

13. Chowdhury SA, Kishino K, Satoh R, Hashimoto K, Kikuchi H, et al (2005) Tumor-specificity and apoptosis-inducing activity of stilbenes and flavonoids. Anticancer Res 25: 2055-2063.
14. https://ntp.niehs.nih.gov/iccvam/suppdocs/feddocs/oecd/ oecdtg407-2008.pdf

15. Borges HL, Linden R, Wang JYJ (2008) DNA damage-induced cell death. Cell Res 18: 17-26.

16. Wang JY, Cho SK (2004) Coordination of repair, checkpoint and cell death responses to DNA damage. Adv Protein Chem 69:101-135.

17. Lorenzo HK, Susin SA, Penninger J, Kroemer G (1999) Apoptosis inducing factor (AIF): Key to the conserved caspse-dependent factor of cell death. Cell Death Differ 6: 516-524. 